\title{
Should Manufacturers Support the Entire Product Lifecycle with Services?
}

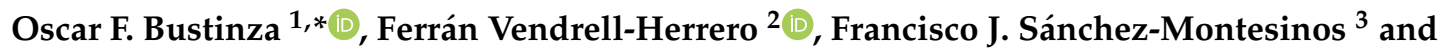 \\ José Antonio Campos-Granados ${ }^{4}$ (i)
}

1 Department of Management, University of Granada, 18071 Granada, Spain

2 Department of Management, University of Birmingham, Birmingham B15 2TT, UK; f.vendrell-herrero@bham.ac.uk

3 Department of Management, ESIC Business \& Marketing School, 28223 Madrid, Spain; franciscojose.sanchezmontesinos@esic.edu

4 Department of Management, University of Deusto, 48007 Bilbao, Spain; tontxu.campos@deusto.es

* Correspondence: oscarfb@ugr.es; Tel.: +34-958-241-000

Citation: Bustinza, O.F.;

Vendrell-Herrero, F;

Sánchez-Montesinos, F.J.

Campos-Granados, J.A. Should Manufacturers Support the Entire Product Lifecycle with Services? Sustainability 2021, 13, 2493.

https://doi.org/10.3390/su13052493

Academic Editor: JinHyo Joseph Yun

Received: 15 January 2021

Accepted: 20 February 2021

Published: 25 February 2021

Publisher's Note: MDPI stays neutral with regard to jurisdictional claims in published maps and institutional affiliations.

Copyright: (c) 2021 by the authors. Licensee MDPI, Basel, Switzerland. This article is an open access article distributed under the terms and conditions of the Creative Commons Attribution (CC BY) license (https:// creativecommons.org/licenses/by/ $4.0 /)$.

\begin{abstract}
The growing trend to develop product-service innovation (PSI) in manufacturing industries has forced firms to consider the real impact of adding services to their sales portfolio. Literature has shown that PSI implementation has heterogeneous effects on performance as it depends on the service development choice and the specific industry in which firms compete. Moreover, PSI implementation has differing effects on performance depending on the manufacturer's position in the value ecosystem. Although the heterogeneous PSI-performance relationship has previously been studied in terms of its intensity, research has not yet examined whether services should support specific stages or the entire product lifecycle. For shedding light on this issue, a fuzzy-set qualitative comparative analysis (fsQCA) is carried out on a sample of Basque firms that operate in the machine manufacturing sector. This useful technique uncovers a set of specific service combinations that maximize manufacturers' profit margin and ratio of solvency. As a result, this study is novel in analyzing the service provision over the entire product lifecycle and reveals that although some service complementarities do exist, single or bundled service specialization outperforms an integral and diversified service approach.
\end{abstract}

Keywords: product-service innovation; servitization; sustainability; performance; product lifecycle

\section{Introduction}

Innovation is broadly considered a firm's core capability that sustains an entire competitive position, as product innovation traditionally serves as the critical instrument that enables manufacturing firms to better adapt to a competitive environment [1]. Thus, in an industrial context, product innovation is a critical variable that embraces technical, design, development, management, and commercialization processes for developing new or improved products [2]. Although product innovation is one of the considerations for advancing firm survival and success [3], it is not exempt of costs and risks. Therefore, understanding the mechanisms that connect product innovation and performance is essential for manufacturing firms [4]. The introduction of service innovation complementary to product innovation as a new manufacturing competitive strategy, a complex innovation known as servitization, or product-service innovation (PSI) [5], has added more nuances in the performance-enhancement effect of innovation for manufacturers [6-9].

We define PSI as service business models in manufacturing that are supported using digital technology [10] and are focused on leveraging positive outcomes through the interplay of production, processes, and service operations while developing distinctive capabilities. Therefore, PSI can be seen as a paradigm shift for manufacturing that contribute towards the so-called Indutry 4.0 [11], thus enabling market and growth and society development $[12,13]$. Successful examples of PSI business models that have generated 
distinctive capabilities include Rolls-Royce's Total Care, Xerox's Print Management, MAN's Pay-per-Kilometer, Bombardier's Transportation, and Hitachi Rail. These examples demonstrate that PSI is an important source of competitive differentiation for manufacturers. As with other forms of innovation (e.g., [14]), previous studies have reported that PSI has an overall positive impact on productivity and performance (see, e.g., [5]), although there are contextual variations [5,15] and unresolved questions [6]. The impact and importance of digitally enhanced service innovation therefore require further investigation according to the potential benefits as well as the unresolved mechanisms that sustain the PSI-performance relationship.

Some of the contextual factors affecting the PSI-performance relationship are related to industry specificities [14] and the type of PSI developed [15]. For instance, some industry particularities that affect successful PSI include the specific R\&D intensity and the presence of knowledge-intensive business service in the sector in which manufacturers operate [16]. Following this reasoning, the interplay between product life span and the development stage of PSI-basic, intermediate, or advanced-has repercussions on the level of performance reached [17]. To shed light on unexplored issues that could affect the PSI-performance relationship, this study focuses on whether manufacturing firms should specialize or diversify service provision in relation to product lifecycle. According to Brax and Visintin [18], there are eight subsequent stages in product lifecycle-production, business analysis, solution design, supply network design, implementation, operation, support, and disposal-wherein manufacturers can offer specific services to their customers. On the basis of this framework, this study proposes the following research question: Should manufacturing firms offer integral services throughout the entire product lifecycle, or should they specialize in supporting single or bundled stages of the product lifecycle? This is an important question because, despite various calls to consider the impact of product lifecycle on firms' development of PSI (e.g., [19,20]), neither operations management nor industrial marketing scholarly communities have systematically investigated the role of product lifecycle in the relationship between PSI and performance.

To answer the proposed research question, this study analyzes the combinations of service offerings throughout the product lifecycle, assessing which configurations maximize profit margin and/or business solvency. The study focuses on the machine manufacturing sector in the territorial context of the Basque Country (Spain), a place where the sector has a strong tradition, leadership, and institutional support from the regional government, e.g., cluster policy [21]. The sample selected is composed of 53 firms regarding which exhaustive financial data were obtained from the ORBIS database. The statistical approach applied fuzzy-set qualitative comparative analysis (fsQCA), a useful technique for determining the combinations of causal factors that are related to superior outcomes [22]. In sum, our results show that the performance-enhancement effect of PSI reaches a maximum when manufacturing firms specialize in services that support one or a few stages of the product lifecycle. In reaching this result, the present study offers two contributions. First, the study demonstrates that manufacturers do not need to concentrate on developing services for all stages of the product lifecycle; hence, there is an advantage to specializing in services that generate the highest value-add. Second, optimal service configurations depend on the firm goal of covering operating costs (e.g., profit margin) or satisfying long-term obligations (e.g., business solvency).

Following this introduction, a literature review of product, service, and combined product-service lifecycle that continues with the hypothesis development is presented. Following this, the methodology section will describe the sample and data gathered and the methodological approach applied to test the hypotheses. Finally, a section describing results and discussion will precede the final conclusions section, wherein future research lines are proposed. 


\section{Background Literature}

\subsection{Product Lifecycle and Service Lifecycle}

When analyzing products, Hepperle et al. [23] proposed a product's lifecycle model containing nine superordinate phases that incorporates principles of engineering design: (1) product planning; (2) product development and design, including the clarification of goals, structuring of problems, proposition of main solutions, structuring and prioritization of work activities and related materials, definition of model components, and simulation and testing of prototypes; (3) process preparation, wherein materials and production are planned, as well as the organization of logistics and control activities; (4) production, composed of manufacturing, assembly, and testing activities; (5) distribution, including warehousing, packaging, and transportation activities; (6) product procurement and utilization; (7) maintenance; (8) modernization and upgrade; and (9) product disposal. The product lifecycle phases definitions from Hepperle et al. [23] are depicted in Table 1.

Table 1. Product lifecycle phases from Hepperle et al. [23].

\begin{tabular}{ll}
\hline \multicolumn{1}{c}{ Phases } & \multicolumn{1}{c}{ Definition (Author) } \\
\hline Product planning & $\begin{array}{l}\text { "Process of envisioning, conceptualizing, developing, producing, testing, commercializing, } \\
\text { sustaining, and disposing of organizational offerings to satisfy consumer needs/wants and } \\
\text { achieve organizational objectives" [24] (p. 1). }\end{array}$ \\
\hline Product development and design & $\begin{array}{l}\text { "Process that incorporates product's concept development, system design, and detail design, } \\
\text { and testing and refinement stages" [25] (p. 103). }\end{array}$ \\
\hline Process preparation & $\begin{array}{l}\text { "Activity that involves product structure manufacturability evaluation, technological process } \\
\text { design, tooling design, production process preparation and production process organization" } \\
\text { [26] (p. 400). }\end{array}$ \\
\hline Production & $\begin{array}{l}\text { Phase that begins with pilot runs carried out in a production system intended for commercial } \\
\text { use and ends when manufacturing start-up begins with low to high volume production [27]. }\end{array}$ \\
\hline Distribution & $\begin{array}{l}\text { "This phase includes details of packaging, loading, transportation, unloading, and interim } \\
\text { storage of the product" [28] (p. 99). }\end{array}$ \\
\hline “tilization & $\begin{array}{l}\text { “This phase includes details of installation, use, maintenance, and repair of the product" [28] } \\
\text { (p. 99). }\end{array}$ \\
\hline Maintenance & $\begin{array}{l}\text { It can be defined as the process of ensuring that a system continually performs its intended } \\
\text { function at its designed-in level of reliability and safety [29]. }\end{array}$ \\
\hline Modernization and upgrade & \begin{tabular}{l} 
It consists on adding or exchanging additional modules during product use phase [30]. \\
\hline Product disposal
\end{tabular} \\
\hline
\end{tabular}

Alternatively, as presented in Table 2, when services are analyzed in isolation, literature shows that service lifecycle is composed of three subsequent phases of service creation, service engineering, and service operations management [32]. Service engineering can be further divided in four sub-phases of service design, service requirements, service testing, and service implementation [32].

The above discussion presents the main frameworks that describe product lifecycle and service lifecycle in the literature. The combined product-service lifecycle framework will be described in the next section.

Table 2. Service lifecycle stages of Wiesner et al. [32].

Service creation

Service engineering: systematic development of services using suitable models, methods, and tools [34].
Process that incorporates the following phases to create services: requirements capture, analysis, specifications, design, implementation, testing, and validation [33].

Service design: The work of specifying an idea about a new service in drawings and specification covering the whole process, from idea to specification $[35,36]$. 
Table 2. Cont.

Service requirements: Process of identifying (1) service entities' functions, (2) service interfaces, (3) service interoperability, and (4) service level agreements [37].

Service testing: A process that begins with the creation of service blueprints and the analyses of critical factors, followed by the creation of test scenarios that incorporate service simulations in terms of landscape, processes, and interactions, and ending with a guideline for service implementation [38].

Service implementation: "Process of moving from a well-designed service concept and service delivery process to a situation wherein delivery of the intended service experience is repeatable and constant" [39] (p. 206). are possible: reuse, waste, or recycle [31].

\subsection{Integrative Model of Product and Service Lifecycles}

Brax and Visintin [18] developed an integrative model that introduces an eight-stage product lifecycle for manufacturing firms that offer services: (1) production (product design, hardware production, and software production), (2) business analysis (business consulting), (3) solution design (technical environment analysis, system requirement specification, maintenance plan, customer training requirement definition, functional design, technical design, and service level agreement definition), (4) supply network design, (5) implementation (installation services, system engineering services, field engineering services, and training), (6) operation (system operation and system-enabled process management), (7) support (maintenance, on-field support, spare and consumables provision, and remote support), and (8) disposal (collecting and transportation, brokering for re-sales, and recycling). These product lifecycle stages constitute a consensual framework in the PSI literature, and as exhibited in Table 3, these stages can be integrated with the previously introduced frameworks.

Table 3. Integrative framework of product and service lifecycles.

\begin{tabular}{lll}
\hline \multicolumn{1}{c}{ Hepperle et al. [23] } & \multicolumn{1}{c}{ Wiesner et al. [32]. } & \multicolumn{1}{c}{ Brax and Visintin [18] } \\
\hline (Pure product firms) & (Pure service firms) & (Product firms offering services) \\
\hline 1. Product planning & \multicolumn{1}{c}{ 1. Service creation } & 2. Business analysis and consulting \\
\hline 2. Product development and design & 2.1. Service design & 3. Solution design \\
\cline { 2 - 3 } & 2.2. Service requirements & 4. Supply network design \\
\hline 3. Process preparation & 2.3. Service testing & 5. Implementation /installation \\
\hline 4. Production & 2.4. Service implementation & 6. Operation \\
\hline 5. Distribution & & 7. Support \\
\hline 6. Utilization & & 8. Disposal \\
\hline 7. Maintenance & 3. Service operations management & \\
\hline 8. Modernization and upgrade & &
\end{tabular}

Business consulting was defined by Greiner and Metzger [40] (p. 7) as "an advisory service contracted for and provided to organizations by specially trained and qualified persons who assist, in an objective and independent manner, the client organization to 
identify management problems, analyze such problems, and recommend solutions to these problems and help when requested in the implementation of solutions." In the context of PSI, consulting services include documentation of the technical environment analysis or system consulting categories such as system requirement specifications [18]. Aurich, Fuchs, and Wagenknecht [41] suggested paying special attention to the solution design stage, as products and services follow different design processes. For products, the processes include idea discovery, conceptual development, product construction, product detailing, prototype development, and manufacturing preparation, whereas for services, the processes include identifying demands, feasibility analysis, concept development, service modeling, realization planning, and service testing. Supply network design considers different dimensions as it is a challenge stage. These dimensions [42] incorporate the following: (a) analysis of the current supply chain network structure, including considerations of network connectivity structure, composition, levels of horizontal and vertical integration, location, or coordination; (b) the flow of information and materials analyzing the activities and processes involved, network dimensions, infrastructure, and IT systems used; (c) roles, relationships, and governance structure for understanding the nature of the transactions and interactions, as well as the complexity and trust between partners; and (d) value structure in terms of product components and replenishment through life services and platforms.

PSI implementation involves multiple critical activities, such as installation, the development of software and applications, system integration, and end users' training [18]. Once a system is installed, firms' operations continuously collect valuable data from the different equipment and users for assessment to improve production efficiency $[43,44]$. That stage is the base for the subsequent lifecycle support stage, as the analysis of the data collected is key to the development of maintenance cost planning. The PSI support stage includes services such as maintenance and repair, spare and consumable provision, product upgrades, helpdesk/customer support centers, and ongoing training [45]. Finally, the PSI disposal stage includes product remanufacturing, reuse, or recycling, and service decommissioning, redesign, and reengineering [46]. Overall, the PSI lifecycle needs to encompass both product and service lifecycles.

\section{Hypotheses Development}

PSI is linked to strategic aspects of an organization, including specialization and vertical/horizontal/systematic integration. Following Gao et al. [47], specialization relates to a firm's capacity for introducing products and related innovative technologies that allow the creation of technological barriers. Horizontal integration is linked to the capacity for adding as many services as possible during the entire product lifecycle, to the capacity for segmenting the market and finding niche markets, and to penetration strategy when firms identify an emerging market. Vertical integration is often related to cost-leading firms with few requirements to penetrate a particular industry segment. Finally, systematic integration refers to the capacity of cost-leading firms to extend their business to new market segments.

Altogether, PSI seems to perform better when focused on solving specific problems that normally involve a high degree of R\&D investment [5] and product complexity [17]. This is because value-added services that solve complex customer demands are usually specific in nature. Therefore, on the basis of this argument, we hypothesize that firms developing simultaneous PSI should specialize in improving the value generation of one phase (or a few complementary phases) of the product lifecycle:

Hypothesis 1 (H1). Firm performance in PSI is highest when manufacturing firms support development of services for one or a few stages of the product lifecycle rather than providing integral services to support the entire product lifecycle.

A wide range of studies associate PSI with performance. For instance, some studies associate PSI with revenue and profitability [48], whereas other studies focus on firms' 
competitive advantage [49-51]. The reasons for the lack of consensus on the relationship between PSI and performance can be found in the contextual differences associated with the relationship [6,50]. For Baines, Lightfoot, and Smart [52], successfully adding services to manufacturing requires the appropriate selection of services that should be incorporated into the firm's offering portfolio. For authors such as Opazo-Basaéz, Vendrell-Herrero, and Bustinza [10] and Marić and Opazo-Basaéz [53], the higher the digital support for services, the higher the level of performance reached, demonstrating once again that the choice of appropriate service mix is critical for reaching superior performance levels.

Service plays a critical role in an operations' product lifecycle stage, as it allows the collection of data and monitoring of customers and identifies potential actions to improve production efficiency [44], making it plausible to assume that service provision considerations represent an inflection point in the entire product lifecycle. More specifically, the product-service lifecycle framework opens different windows for manufacturing firms to offer specific services according to various product lifecycle stages. Therefore, optimal services can be added on the basis of different product lifecycle stages, from the initial phases, wherein manufacturers aim to decrease the risks associated with any given position by increasing short-term liquidity or profit margin [54], to the final phases, wherein firms seek to pay maturing debt or long-term solvency [55]. On the basis of these arguments, we have the following hypotheses:

Hypothesis 2 (H2a). The presence of one or two PSI offerings in the initial phases of a product lifecycle (business analysis, solution design, supply network design, implementation, and operation) is linked to strong profit margin in manufacturing.

Hypothesis $\mathbf{2}(\mathbf{H} \mathbf{2 b})$. The presence of one or two PSI offerings in the final phases of a product lifecycle (operation, support, and disposal) is linked to strong solvency in manufacturing.

\section{Method}

\subsection{Sample}

This research focuses on the manufacturing industry in the Basque Country, a region located in northern Spain that borders both France and the Cantabric Sea. The Basque Country leads the Spanish innovation manufacturing ecosystem [56] and is currently in the process of a digital transformation that includes a wide range of service offerings $[53,57,58]$. We focus specifically on the machine manufacturing industry, one of the leading Basque industries, with extensive roots in the regional economic ecosystem [21,59]. According to the North American Industry Classification System (NAICS), a standard system for classifying industries, the machine manufacturing industry (NAICS code 333) is "responsible for creating end products that apply mechanical force, including processes for the manufacture of machinery such as forging, stamping, bending, forming, and machining that are used to shape individual pieces of metal. Complex assembly operations are an inherent part of the production process, while design is considered to be part of the previously introduced production process. It includes general and special purpose machinery." (Definition is taken from the North American Industry Classification System webpage (www.naics.com). Accessed on 7 July 2020).

The population selected for this study consists of Basque firms in the machine manufacturing industry that were economically active in 2019, leaving aside the effects of the COVID-19 pandemic. Data were gathered through the ORBIS database, a comprehensive data resource that provides accounting information of private companies. Hence, the search strategy consisted in selecting manufacturing firms in the Basque Country in 2019, with the primary NAICS code 333 "Machine Manufacturing," resulting in the identification of 430 firms operating in the machine manufacturing industry. This initial search was further refined by following the approach of Gomes et al. [60]. These authors determined that manufacturing firms adopted PSI if they reported secondary industry codes belonging 
to services; 53 firms reported those secondary codes, representing $12.3 \%$ of the firms in the machine manufacturing industry, a ratio considerably above the European average [61].

More specifically, we considered NAICS service codes 518-519 for IT services; 54 for Professional, Scientific, and Technical Services; 56 for Administrative and Support and Waste Management and Remediation Services; and 811 for Repair and Maintenance Services. An exhaustive analysis of the information provided by ORBIS complemented by firm websites allowed us to classify firms into the different service categories along the product lifecycle as defined by Brax and Visintin [18] (see Table 3). Most of these services are in the form of industrial patterns. As an example of the process used when assessing these industrial services, DANOBATGROUPS (https:/ / www.danobatgroup. com/en/customer-support, accessed on 14 July 2020) is a machine tool manufacturing firm that offers process engineering, maintenance, training, diagnosis, remote support, upgrading of software-hardware, and digital services, among others.

\subsection{Causal Variables and Outcomes: fsQCA Analysis}

Considering that the observed firms can offer seven different services (production lifecycle stage from Brax and Visintin [18] is not included; that is why we have seven out of eight lifecycle stages), each of them related to a particular product lifecycle phase. The methodological approach needs to be capable of analyzing which combination of services (causal variable) is linked to superior performance (outcome variable). We opt for fsQCA, as it allows an analysis of different combinations of causal and outcome conditions, eliciting explanatory power for each of the combinations [62]. This methodology allows the use of dichotomous variables (in our study, firms can offer the service, meaning value 1, or not, meaning value 0 ) and fuzzy-set variables, i.e., variables that have different values and need to be calibrated in specific intervals, through assigning fuzzy conditions of labeling anchors of belonging (fully in, almost fully in, neither more in nor more out, barely more out than in, etc.). Calibration is for 0 to 1 , whereas the usual crossover point is 0.5 . There are two general calibration methods: direct, wherein the researcher chooses the anchors, and indirect, wherein the software selects the anchors by function of the type of variable. We use the QCA package for R software and make a cluster analysis [63] (p. 87) to establish which threshold values (complete exclusion, crossover point, and complete inclusion) best separate the points into a certain number of groups. Following this, we apply a logistic approach to the variables for converting them into an s-shaped function as, as said before, thresholds contain three values. Our study analyzed which combinations of causal conditions (offering business analysis, solution design, supply network design, implementation, operations, support, and/or disposal services) are linked to a specific outcome (profit margin and solvency ratio) (These performance variables have been used extensively in previous studies. For an explanation on how these outcome variables are measured, see the ORBIS webpage (www.bvdinfo.com). Accessed on 7 July 2020).

\section{Results}

\subsection{Analysis of Necessity}

A variable is necessary for another to occur when the variable is present in all instances that the target variable occurs [63] (p. 111). R's function pof() performs an analysis of necessity and reports three different values: inclN, denoting the inclusion necessity value or consistency value, wherein values higher than 0.9 indicate conditions that are necessary or almost always necessary; RoN, indicating relevance of necessity, meaning the lower the value, the higher the triviality of a condition, with an accepted threshold value of 0.6 for this parameter; and $\operatorname{cov} N$, a measure of how trivial a condition is (positive values indicate that a condition is not trivial). The necessary analysis for the performance outcome to occur when a given service is offered is shown in Table 4. Accordingly, none of the inclusion necessity values are higher than 0.9 , meaning none of the conditions in isolation are necessary to achieve the highest performance, in terms of profit margin or solvency ratio, while all the conditions are not trivial. 
Table 4. Analysis of necessary and sufficiency conditions.

\begin{tabular}{ccccccccccc}
\hline & \multicolumn{4}{c}{ Presence of Profit Margin (PM) } & \multicolumn{3}{c}{ Absence of PM } \\
\hline Condition & inclN & RoN & covN & inclS & PRI & covS & inclS & PRI & covS \\
\hline Business analysis (BA) & 0.160 & 0.988 & 0.796 & 0.796 & 0.744 & 0.06 & 0.204 & 0.010 & 0.045 \\
Solution design (SD) & 0.348 & 0.866 & 0.723 & 0.723 & 0.677 & 0.348 & 0.277 & 0.157 & 0.390 \\
Supply network design (SN) & 0.118 & 0.995 & 0.722 & 0.722 & 0.616 & 0.018 & 0.278 & 0.012 & 0.021 \\
Implementation (IM) & 0.226 & 0.908 & 0.688 & 0.688 & 0.646 & 0.226 & 0.312 & 0.222 & 0.301 \\
Operation (OP) & 0.332 & 0.877 & 0.728 & 0.728 & 0.687 & 0.332 & 0.272 & 0.163 & 0.363 \\
Support (SU) & 0.597 & 0.748 & 0.760 & 0.760 & 0.700 & 0.597 & 0.240 & 0.047 & 0.550 \\
Disposal (DI) & 0.511 & 0.793 & 0.748 & 0.748 & 0.682 & 0.511 & 0.252 & 0.054 & 0.504 \\
\hline & & & Solvency ratio (SR) & & & & Absence of PM \\
\hline Condition & inclN & RoN & covN & inclS & PRI & covS & inclS & PRI & covS \\
\hline Business analysis (BA) & 0.163 & 0.995 & 0.801 & 0.818 & 0.810 & 0.063 & 0.082 & 0.011 & 0.027 \\
Solution design (SD) & 0.333 & 0.887 & 0.771 & 0.771 & 0.726 & 0.333 & 0.229 & 0.077 & 0.480 \\
Supply network design (SN) & 0.118 & 0.996 & 0.795 & 0.795 & 0.742 & 0.018 & 0.205 & 0.012 & 0.023 \\
Implementation (IM) & 0.220 & 0.923 & 0.744 & 0.744 & 0.694 & 0.220 & 0.256 & 0.113 & 0.368 \\
Operation (OP) & 0.314 & 0.893 & 0.766 & 0.766 & 0.720 & 0.314 & 0.234 & 0.082 & 0.465 \\
Support (SU) & 0.602 & 0.828 & 0.853 & 0.853 & 0.832 & 0.602 & 0.147 & 0.027 & 0.503 \\
Disposal (DI) & 0.532 & 0.877 & 0.865 & 0.865 & 0.849 & 0.532 & 0.135 & 0.031 & 0.402 \\
\hline
\end{tabular}

\subsection{Analysis of Sufficiency}

Sufficiency analysis considers four different values: inclS for measuring inclusion sufficiency; PRI, which measures the proportional reduction in inconsistency (used to compare between necessary conditions for the presence of the outcome and for its absence); $\operatorname{cov} S$, which is the raw coverage, an indicator with similarity to $R$-squared in multivariate analysis, measuring the proportion of the outcome explained [15]; and $\operatorname{cov} U$, expressing unique coverage. As it happens, regarding the analysis of necessity, none of the conditions are sufficient for the outcomes to occur (see Table 4).

\subsection{True Table}

Causal conditions take values from 0 to 1 . Therefore, the analysis of necessity for a positive outcome to occur means that the analysis of necessity for the absence of the outcome to occur is equal to $1-i n c l N$. That means, for instance, that business analysis (BA), with a consistency value of $1-0.160=0.840$, for the absence of PM to occur, does not reach the threshold value of 0.9 that ensures necessity. The same occurs for the rest of the causal conditions. Therefore, none of the conditions are necessary for having negative PMs or solvency ratios. To find the minimal configurations of conditions that are sufficient for PM and SR, QCA methodology uses an algorithm to create a truth table that determines whether causes and effects support or do not support our hypotheses. R QCA software offers three solutions: complex, intermediate, and parsimonious. For interpretation of results, intermediate solutions are recommended, as it represents a compromise between complexity and parsimony $[62,64]$. The presence of a condition is expressed in capital letters, whereas absence is expressed by the symbol " ." A conjunction of conditions is expressed by " "*, whereas different conjunctions of conditions behind the occurrence of an outcome are expressed by "+." The following are the results for superior profit margin $(P M)$, intuitively represented in the following notation:

$$
\begin{gathered}
S D * \sim O P+B A * S D * I M * O P+\sim B A * \sim S D * \sim S N * O P * \sim D I \rightarrow P M \\
\text { incl } S=0.858 ; P R I=0.835 ; \operatorname{cov} S=0.174
\end{gathered}
$$

where inclS is the sufficiency inclusion score; $P R I$ is the proportional reduction in inconsistency, and $\operatorname{cov} S$ is the solution coverage that can be interpreted as the explanatory power of the solution over the outcome. 
Regarding the intermediate solutions for solvency ratio (SR), we can remark that the explanatory power expressed by solution coverage, as can be seen below, is 0.607 , a remarkable value indeed. Table 5 presents the PSI causal configurations that achieve superior PM and SR.

$$
\begin{gathered}
\sim S N * \sim I M * O P+\sim S N * \sim I M * S U * D I \rightarrow S R \\
\text { inclS }=0.861 ; P R I=0.841 ; \operatorname{cov} S=0.607
\end{gathered}
$$

\begin{tabular}{|c|c|c|c|c|c|c|}
\hline \multicolumn{7}{|c|}{ Outcome Variable. } \\
\hline \multicolumn{7}{|c|}{ Performance (Profit Margin) } \\
\hline $\begin{array}{l}\text { Business } \\
\text { analysis }\end{array}$ & $\begin{array}{l}\text { Solution } \\
\text { design }\end{array}$ & $\begin{array}{c}\text { Supply } \\
\text { network } \\
\text { design }\end{array}$ & Implementation & Operation & Support & Disposal \\
\hline- & $\bullet$ & - & - & 0 & - & - \\
\hline - & $\bullet$ & - & $\bullet$ & - & - & - \\
\hline$\bigcirc$ & $\bigcirc$ & $\bigcirc$ & - & $\bullet$ & - & $\bigcirc$ \\
\hline \multicolumn{7}{|c|}{ Solution sufficiency $=0.858 /$ Solution coverage $=0.174$} \\
\hline \multicolumn{7}{|c|}{ Performance (Solvency Ratio) } \\
\hline $\begin{array}{l}\text { Business } \\
\text { analysis }\end{array}$ & $\begin{array}{l}\text { Solution } \\
\text { design }\end{array}$ & $\begin{array}{c}\text { Supply } \\
\text { network } \\
\text { design }\end{array}$ & Implementation & Operation & Support & Disposal \\
\hline- & - & $\bigcirc$ & $\bigcirc$ & $\bullet$ & - & - \\
\hline- & - & $\bigcirc$ & $\bigcirc$ & - & $\bullet$ & $\bullet$ \\
\hline \multicolumn{7}{|c|}{ Solution sufficiency $=0.861 /$ Solutions coverage $=0.607$} \\
\hline
\end{tabular}

Table 5. Product-service innovation (PSI) implementation, product-service lifecycle phase, and performance.

Black circles "•" indicate that companies implement these innovations, unfilled circles " $\bigcirc$ " indicate that they do not implement these innovations, and a hyphen " - " indicates indifference.

\subsection{Discussion}

These results support hypothesis 1 , which argued that manufacturers implementing PSI would obtain superior profit margin and solvency ratio by offering a single service or specific bundles of services instead of providing an integral package of services to support the entire product lifecycle. These findings are in line with previous research demonstrating that specific types of services are more related to performance. For instance, Sousa and da Silveira [65] showed that base (aimed to install and maintain product functionality) and advanced services (customization of the product to the specific customer's needs and usage situation), but not intermediate services (in which the outcome focuses on the product provision), are antecedents of performance. Similarly, Bustinza et al. [15] established that specific combinations of the previously introduced types of services (base, intermediate, and advanced) were related to superior performance in function of the industry in which manufacturers operate, being firms' responsibility for deciding which type of service to offer and how to develop it, whether in-house or through partnership.

The results also support hypotheses $2 a$ and $2 b$, revealing that specific single or bundled PSI offerings in the initial phases of product lifecycle, i.e., those specifically incorporating business analysis (BA), solution design, implementation, and operation services, are related to superior PM, whereas specific single or bundled PSI offerings in the final phases, i.e., those specifically incorporating operation, support, and disposal services, are linked to superior solvency for machine industry manufacturers. Interestingly, operation servicessystem operation and system-enabled process management services-are the only services that are a causal condition in both the combinations behind PM and SR. Operation services are responsible for collecting data from equipment and users in different environments 
while creating the means for interconnecting the system [44]; therefore, such services improve efficiency in both the short and long run.

Finally, to better visualize the results, Table 6 presents the percentage of firms that implement the services that were deemed causal conditions for achieving superior performance. For instance, only $5.66 \%$ of the firms specialize in business analysis, whereas $33.96 \%$ of firms specialize in offering operation services. Regarding causal combinations behind PM, only $9.43 \%$ of firms offer any of the product initial lifecycle packages that represent performance competence, whereas $52.83 \%$ of the firms offer any of the product final lifecycle packages. The results indicate the specific investments that manufacturers must make on PSI to be more profitable or solvent, while also revealing the service development investments that should be discarded. Moreover, the results demonstrate that there are specific product lifecycle service packages to be developed and offered in order to maximize profits or, alternatively, to improve solvency. The results are in congruence with previous research that showed the heterogeneity between servitization and performance [6].

Table 6. PSI strategy implementation behind performance outcomes.

\begin{tabular}{lcc}
\hline \multicolumn{1}{c}{ PSI Strategy } & Outcome Variable & $\%$ Firms \\
\hline Specialization in business analysis & Profit margin & $5.66 \%$ \\
\hline Specialization in solutions design & Profit margin & $35.85 \%$ \\
\hline Specialization in implementation & Profit margin & $24.53 \%$ \\
\hline Specialization in operations & Profit margin and solvency & $33.96 \%$ \\
\hline Specialization in support & Solvency ratio & $58.49 \%$ \\
\hline Specialization in disposal & Solvency ratio & $50.94 \%$ \\
\hline Product initial lifecycle services package & Profit margin & $9.43 \%$ \\
\hline Product final lifecycle services package & Solvency ratio & $52.83 \%$ \\
\hline
\end{tabular}

\section{Discussion and Conclusions}

\subsection{Theoretical Implications}

PSI has been extensively related to private [49] and social [66,67] benefits, yet positive outcomes are not always guaranteed [8,45]. Those inconclusive positive effects of PSI on performance are due to contextual factors such as industry and technological environments $[5,15]$ or product complexity [17]. The current research pioneers an analysis of the different stages on product lifecycle when manufacturers can offer a single or bundled complementary service. Therefore, this paper continues the research to uncover the nuances behind the PSI-performance relationship by offering a novel approach for obtaining dual performance outcomes related to short- and long-term firm perspectives.

As indicated in the title, this study answers the question of whether manufacturers should offer services to add value to all phases of the product lifecycle or, alternatively, manufacturers should specialize in certain phases of the product lifecycle. We answer this question in three steps. In the first place, although the vast majority of the machinery manufacturing companies in our sample do not offer services $(88 \%)$, this ratio is lower than that in other manufacturing industries in Europe, wherein approximately $95 \%$ of manufacturing companies still do not adopt PSI [61]. Second, we argue and empirically demonstrate that manufacturing companies perform better by focusing on specific phases of the product lifecycle, such as operations. Finally, we argue that adding services early in the product lifecycle promotes product differentiation. For example, co-creation with the client enables a more customized design, thereby enhancing value generation. We also argue that services associated with the final phases of the product lifecycle, such as maintenance or reusage, allow for greater long-term liquidity, thus increasing the SR. Our data strongly validates our arguments.

The results offer four important contributions to the literature. First, we extend the methodology proposed by Gomes et al. [60], revealing how services support different 
phases of the product lifecycle. This method can be easily replicated in other contexts and hence opens the possibility to monitor both the degree of PSI adoption and heterogeneity in terms of product lifecycle support. Second, whereas previous research analyzing PSIperformance relationship focuses on PSI intensity and degree of development (see Bustinza et al. [6,68], or Calle et al. [69]), this research focuses on the PSI configuration and the parts of the product lifecycle that are supported. Third, our theoretical arguments and findings present a plausible explanation as to why the servitization sector does not immediately see the benefits of implementing PSI offerings [9]. Few manufacturing firms in the machine manufacturing sector (less than $10 \%$ ) offer a specific service or bundle of services on products' initial lifecycle stages-business analysis, solution design, implementation, or operation services - to reach superior PM. Conversely, more than half of the firms do offer those specific service or bundled services on the products' final lifecycle stages-operation, support, or disposal services-more related to the ratio of solvency. This is an important contribution that highlights the importance of green services [10] in response to the debate regarding circular economy. Finally, this study provides novel contributions to the PSI and sustainability communities, as it sheds light on the importance of selecting the appropriate service investments that sustain short- and long-term manufacturer financial obligations as well as organizational resilience and circular economy principles.

\subsection{Managerial Implications}

The work offers important managerial implications. Our findings suggest that manufacturers should think about service specialization to improve financial objectives. Therefore, this research is consistent with the idea that services helps manufacturers to develop resilience [70], an important capacity during economic crises. Second, this paper also demonstrates that a specific product lifecycle phase particularly benefits from servicesthat is, operations. This phase is positively associated to both short- and long-term performance measures. Operations are responsible for continuously monitoring and controlling data from equipment and users and are behind subsequent optimization decisions that are the basis for establishing accurate system maintenance costs [43]. This is critically important for manufacturers, as it provides a realistic approach to determining costs as a base for better offering maintenance contracts to their customers.

\subsection{Limitations and Future Research Lines}

This study presents an example of how to evaluate service configurations in relation to product lifecycle phases. The empirical exercise is focused on specific geographic (Basque Country), sectoral (machine manufacturing), and temporal (2019) scopes. Future research will be able to evaluate the service provision during the product lifecycle in other environments and time periods. In this sense, future research should uncover three elements. First, a broader time horizon should be considered. In this regard, it would be particularly interesting to analyze how the course of a prolonged crisis changed the service configuration in companies. For example, during the COVID-19 pandemic, companies may have strengthened remote technologies in order to minimize human contact in the provision of services. Second, future research should analyze the service configurations offered in different industrial environments. It is expected that there will be more services supporting the first phases of the product lifecycle in more customized environments (e.g., military equipment design through co-creation). Third, it would be important to analyze whether the service configuration is different in less developed environments. By having a lower level of production standards and human capital, less developed environments may require greater services that support user training and the environmental efficiency of the product. 
Author Contributions: Conceptualization, O.F.B., F.V.-H., F.J.S.-M. and J.A.C.-G.; methodology, O.F.B., F.V.-H., F.J.S.-M. and J.A.C.-G.; software, O.F.B., F.V.-H., F.J.S.-M. and J.A.C.-G.; validation, O.F.B., F.V.-H., F.J.S.-M. and J.A.C.-G.; formal analysis, O.F.B., F.V.-H., F.J.S.-M. and J.A.C.-G.; investigation, O.F.B., F.V.-H., F.J.S.-M. and J.A.C.-G.; resources, O.F.B., F.V.-H., F.J.S.-M. and J.A.C.-G.; data curation, O.F.B., F.V.-H., F.J.S.-M. and J.A.C.-G.; writing-original draft preparation, O.F.B., F.V.-H., F.J.S.-M. and J.A.C.-G.; writing-review and editing, O.F.B., F.V.-H., F.J.S.-M. and J.A.C.-G.; visualization, O.F.B., F.V.-H., F.J.S.-M. and J.A.C.-G.; supervision, O.F.B., F.V.-H., F.J.S.-M. and J.A.C.-G.; project administration, O.F.B., F.V.-H., F.J.S.-M. and J.A.C.-G.; funding acquisition, F.J.S.-M. and J.A.C.-G. All authors have read and agreed to the published version of the manuscript.

Funding: This research was funded by FEDER/Ministerio de Ciencia, Innovación y UniversidadesAgencia Estatal de Investigación, Spain. grant number PGC2018-101022-A-100.

Informed Consent Statement: Not applicable.

Conflicts of Interest: The authors declare no conflict of interest.

\section{References}

1. Hernández-Espallardo, M.; Delgado-Ballester, E. Product innovation in small manufacturers, market orientation and the industry's five competitive forces. Eur. J. Innov. Manag. 2009, 12, 470-491. [CrossRef]

2. Freeman, C. The Economics of Industrial Innovation; Frances Pinter: London, UK, 1982.

3. Hult, G.T.M.; Hurley, R.F.; Knight, G.A. Innovativeness: Its antecedents and impact on business performance. Ind. Mark. Manag. 2004, 33, 429-438. [CrossRef]

4. Slater, S.F.; Mohr, J.J.; Sengupta, S. Radical product innovation capability: Literature review, synthesis, and illustrative research propositions. J. Prod. Innov. Manag. 2014, 31, 552-566. [CrossRef]

5. Bustinza, O.F.; Gomes, E.; Vendrell-Herrero, F.; Baines, T. Product-service innovation and performance: The role of collaborative partnerships and R\&D intensity. RED Manag. 2019, 49, 33-45. [CrossRef]

6. Bustinza, O.F.; Vendrell-Herrero, F.; Gomes, E.; Lafuente, E.; Opazo-Basáez, M.; Rabetino, R.; Vaillant, Y. Product-service innovation and performance: Unveiling the complexities. Int. J. Bus. Eviron. 2018, 10, 95-111. [CrossRef]

7. Kohtamäki, M.; Partanen, J.; Parida, V.; Wincent, J. Non-linear relationship between industrial service offering and sales growth: The moderating role of network capabilities. Ind. Mark. Manag. 2013, 42, 1374-1385. [CrossRef]

8. Kowalkowski, C.; Windahl, C.; Kindström, D.; Gebauer, H. What service transition? Rethinking established assumptions about manufacturers' service-led growth strategies. Ind. Mark. Manag. 2015, 45, 59-69. [CrossRef]

9. Visnjic-Kastalli, I.V.; Van Looy, B. Servitization: Disentangling the impact of service business model innovation on manufacturing firm performance. J. Oper. Manag. 2013, 31, 169-180. [CrossRef]

10. Opazo-Basáez, M.; Vendrell-Herrero, F.; Bustinza, O.F. Uncovering productivity gains of digital and green servitization: Implications from the automotive industry. Sustainability 2018, 10, 1524. [CrossRef]

11. Dalenogare, L.S.; Benitez, G.B.; Ayala, N.F.; Frank, A.G. The expected contribution of Industry 4.0 technologies for industrial performance. Int. J. Prod. Econ. 2018, 204, 383-394. [CrossRef]

12. Cooke, P.; Yun, J.J.; Zhao, X.; Kim, Y. The digital, quaternary or 4.0 web economy: Aspects, effects and implications. Int. J. Knowl. Based Dev. 2019, 10, 193-212. [CrossRef]

13. Lee, M.; Yun, J.J.; Pyka, A.; Won, D.; Kodama, F.; Schiuma, G.; Park, H.; Jeon, J.; Park, K.; Jung, K.; et al. How to Respond to the Fourth Industrial Revolution, or the Second Information Technology Revolution? Dynamic New Combinations between Technology, Market, and Society through Open Innovation. J. Open Innov. Technol. Mark. Complex. 2018, 4, 21. [CrossRef]

14. Albury, D. Fostering innovate on in public services. Public Money Manag. 2005, 25, 51-56. [CrossRef]

15. Bustinza, O.F.; Lafuente, E.; Rabetino, R.; Vaillant, Y.; Vendrell-Herrero, F. Make-or-buy configurational approaches in productservice ecosystems and performance. J. Bus. Res. 2019, 104, 393-401. [CrossRef]

16. Lafuente, E.; Vaillant, Y.; Vendrell-Herrero, F. Territorial servitization: Exploring the virtuous circle connecting knowledgeintensive services and new manufacturing businesses. Int. J. Prod. Econ. 2017, 192, 19-28. [CrossRef]

17. Vendrell-Herrero, F.; Vaillant, Y.; Bustinza, O.F.; Lafuente, E. Product lifespan: The missing link in servitization. Prod. Plan. Control 2021. In Press. [CrossRef]

18. Brax, S.A.; Visintin, F. Meta-model of servitization: The integrative profiling approach. Ind. Mark. Manag. 2017, 60, 17-32. [CrossRef]

19. Rabetino, R.; Kohtamäki, M.; Lehtonen, H.; Kostama, H. Developing the concept of life-cycle service offering. Ind. Mark. Manag. 2015, 49, 53-66. [CrossRef]

20. Rabetino, R.; Harmsen, W.; Kohtamäki, M.; Sihvonen, J. Structuring servitization-related research. Int. J. Oper. Prod. Manag. 2018, 38, 350-371. [CrossRef]

21. Aranguren, M.J.; De La Maza, X.; Parrilli, M.D.; Vendrell-Herrero, F.; Wilson, J.R. Nested methodological approaches for cluster policy evaluation: An application to the Basque Country. Reg. Stud. 2014, 48, 1547-1562. [CrossRef] 
22. Sjödin, D.R.; Parida, V.; Kohtamäki, M. Capability configurations for advanced service offerings in manufacturing firms: Using fuzzy set qualitative comparative analysis. J. Bus. Res. 2016, 69, 5330-5335. [CrossRef]

23. Hepperle, C.; Thanner, S.; Mörtl, M.; Lindemann, U. An integrated product lifecycle model and interrelations in-between the lifecycle phases. In Proceedings of the 6th International Conference on Product Lifecycle Management, Bath, UK, 6-8 July 2009.

24. Kahn, K.B. Product Planning Essentials; Routledge: Thousand oaks, CA, USA, 2014.

25. Hong, P.; Doll, W.J.; Nahm, A.Y.; Li, X. Knowledge sharing in integrated product development. Eur. J. Innov. Manag. 2004, 7, 102-112. [CrossRef]

26. Tong, Y.F.; Li, D.B.; He, Y. Process preparation resources integration service mode and semantic description in manufacturing grid. In Advanced Engineering Forum; Trans Tech Publications Ltd: Bäch, Sweden, 2011; Volume 1, pp. 400-404.

27. Almgren, H. Pilot production and manufacturing start-up: The case of Volvo S80. Int. J. Prod. Res. 2000, 38, 4577-4588. [CrossRef]

28. Kota, S.; Chakrabarti, A. ACLODS: A holistic framework for product life cycle design. Int. J. Prod. Dev. 2014, 19, 90-112. [CrossRef]

29. Lee, S.G.; Ma, Y.S.; Thimm, G.L.; Verstraeten, J. Product lifecycle management in aviation maintenance, repair and overhaul. Comput. Ind. 2008, 59, 296-303. [CrossRef]

30. Umemori, Y.; Kondoh, S.; Umeda, Y.; Shimomura, Y.; Yoshioka, M. Design for upgradable products considering future uncertainty. In Proceedings of the Second International Symposium on Environmentally Conscious Design and Inverse Manufacturing, Tokyo, Japan, 11-15 December 2001; pp. 87-92.

31. Chiabert, P.; Lombardi, F.; Sauza Bedolla, J.; Martinez Gomez, J. Visualization model for product lifecycle management. Ann. Fac. Eng. Hunedoara 2013, 11, 109-116.

32. Wiesner, S.; Guglielmina, C.; Gusmeroli, S.; Dougmeingts, G. Manufacturing Service Ecosystem; Mainz Verlag: Aachen, Germany, 2014.

33. Mudhar, P. A service creation environment for a future intelligent network. In International Conference on Intelligence in Services and Networks; Springer: Berlin/Heidelberg, Germany, 1994; pp. 333-342.

34. Bullinger, H.J.; Fähnrich, K.P.; Meiren, T. Service engineering methodical development of new service products. Int. J. Prod. Econ. 2003, 85, 275-287. [CrossRef]

35. Norling, P.; Edvardsson, B.; Gummesson, E. Tjänsteut-Veckling och Tjänstekonstruction. Research Report 92(5); Service Research Center, University of Karlstad: Karlstad, Sweden, 1992.

36. Zeithaml, V.A.; Berry, L.L.; Parasuraman, A. Delivering Quality Service: Balancing Customer Perceptions and Expectations; Free Press: New York, NY, USA, 1990.

37. Suhardi, S.; Doss, R.; Yustianto, P. Service engineering based on service oriented architecture methodology. TELKOMNIKA (Telecommun. Comput. Electron. Control.) 2015, 13, 1466-1477. [CrossRef]

38. Meiren, T.; Burger, T. Testing of service concepts. Serv. Ind. J. 2010, 30, 621-632. [CrossRef]

39. Overkamp, T.; Holmlid, S. Views on implementation and how they could be used in service design. In Service Design Geographies. Proceedings the ServDes. 2016 Conference; Linköping University Electronic Press: Linköping, Sweden, 2016; Volume 125, pp. 205-214.

40. Greiner, L.E.; Metzger, R.O. Consulting to Management; Prentice-Hall: Englewood Cliffs, NJ, USA, 1983.

41. Aurich, J.C.; Fuchs, C.; Wagenknecht, C. Life cycle oriented design of technical Product-Service Systems. J. Clean. Prod. 2006, 14, 1480-1494. [CrossRef]

42. Srai, J.S.; Gregory, M. A supply network configuration perspective on international supply chain development. Int. J. Oper. Prod. Manag. 2008, 28, 386-411. [CrossRef]

43. Opresnik, D.; Taisch, M. The value of big data in servitization. Int. J. Prod. Econ. 2015, 165, 174-184. [CrossRef]

44. Wang, N.; Ren, S.; Liu, Y.; Yang, M.; Wang, J.; Huisingh, D. An active preventive maintenance approach of complex equipment based on a novel product-service system operation mode. J. Clean. Prod. 2020, 277, 123365. [CrossRef]

45. Gebauer, H.; Fleisch, E.; Friedli, T. Overcoming the service paradox in manufacturing companies. Eur. Manag. J. 2005, 23, 14-26. [CrossRef]

46. Cavalcante, J.; Gzara, L. Product-Service Systems Lifecycle Models: Literature Rev. and New Proposition. In Proceedings of the 10th CIRP Conference on Industrial Product-Service Systems, IPS2 2018, Linköping, Sweden, 29-31 May 2018.

47. Gao, J.; Yao, Y.; Zhu, V.C.; Sun, L.; Lin, L. Service-oriented manufacturing: A new product pattern and manufacturing paradigm. J. Intell. Manuf. 2011, 22, 435-446. [CrossRef]

48. Crozet, M.; Milet, E. Should everybody be in services? The effect of servitization on manufacturing firm performance. J. Econ. Manag. Strategy 2017, 26, 820-841. [CrossRef]

49. Baines, T.; Bigdeli, A.Z.; Bustinza, O.F.; Shi, V.G.; Baldwin, J.; Ridgway, K. Servitization: Revisiting the state-of-the-art and research priorities. Int. J. Oper. Prod. Manag. 2017, 37, 256-278. [CrossRef]

50. Bustinza, O.F.; Vendrell-Herrero, F.; Baines, T. Service implementation in manufacturing: An organisational transformation perspective. Int. J. Prod. Econ. 2017, 192, 1-8. [CrossRef]

51. Vendrell-Herrero, F.; Bustinza, O.F.; Parry, G.; Georgantzis, N. Servitization, digitization and supply chain interdependency. Ind. Mark. Manag. 2017, 60, 69-81. [CrossRef]

52. Baines, T.; Lightfoot, H.; Smart, P. Servitization within manufacturing. J. Manuf. Technol. Manag. 2011, 22, 947-954. [CrossRef]

53. Marić, J.; Opazo-Basáez, M. Green servitization for flexible and sustainable supply chain operations: A review of reverse logistics services in manufacturing. Global J. Flex. Syst. Manag. 2019, 20, 65-80. [CrossRef] 
54. Walter, J.E. Determination of technical solvency. J. Bus. 1957, 30, 30-43. [CrossRef]

55. Fu, G.; Fu, W.; Liu, D. Empirical study on financial risk factors: Capital structure, operation ability, profitability, and solvency: Evidence from listed companies in China. J. Bus. Manag. Econ. 2012, 3, 173-178.

56. González-Pernía, J.L.; Peña-Legazkue, I.; Vendrell-Herrero, F. Innovation, entrepreneurial activity and competitiveness at a sub-national level. Small Bus. Econ. 2012, 39, 561-574. [CrossRef]

57. Galera-Zarco, C.; Opazo-Basáez, M.; Marić, J.; García-Feijoo, M. Digitalization and the inception of concentric strategic alliances: A case study in the retailing sector. Strateg. Chang. 2000, 29, 165-177. [CrossRef]

58. Opazo-Basáez, M.O.; Cantín, L.N.; Granados, J.A.C. Does distance really matter? Assessing the impact of KIBS proximity on firms' servitization capacity: Evidence from the Basque country. Investig. Reg. J. Reg. Res. 2020, 48, 51-68. [CrossRef]

59. Paiva, E.L.; Gutierrez, E.R.; Roth, A.V. Manufacturing strategy process and organizational knowledge: A cross-country analysis. J. Knowl. Manag. 2012, 16, 302-328. [CrossRef]

60. Gomes, E.; Bustinza, O.F.; Tarba, S.; Khan, Z.; Ahammad, M. Antecedents and implications of territorial servitization. Reg. Stud. 2019, 53, 410-423. [CrossRef]

61. Vendrell-Herrero, F.; Bustinza, O.F. Servitization in Europe. In Industry 4.0 and Regional Transformation; De Propris, L., Bailey, D., Eds.; Routledge: London, UK, 2020; pp. 24-41, ISBN 978-0-367-17841-3.

62. Rihoux, B.; Ragin, C.C. Configurational Comparative Methods: Qualitative Comparative Analysis (QCA) and Related Techniques; Sage Publications: Thousand Oaks, CA, USA, 2008; Volume 51.

63. Duşa, A. QCA with R: A Comprehensive Resource; Springer: Berlin, Germany, 2018.

64. Schneider, M.R.; Schulze-Bentrop, C.; Paunescu, M. Mapping the institutional capital of high-tech firms: A fuzzy-set analysis of capitalist variety and export performance. J. Int. Bus. Stud. 2010, 41, 246-266. [CrossRef]

65. Sousa, R.; da Silveira, G.J. Capability antecedents and performance outcomes of servitization. Int. J. Oper. Prod. Manag. 2017, 37, 444-467. [CrossRef]

66. Yun, J.J.; Jung, W.; Yang, J. Knowledge strategy and business model conditions for sustainable growth of SMEs. J. Sci. Technol. Policy Manag. 2015, 6, 246. [CrossRef]

67. Yun, J.J.; Park, K.; Im, C.; Shin, C.; Zhao, X. Dynamics of social enterprises: Shift from social innovation to open innovation. Sci. Technol. Soc. 2017, 22, 425-439. [CrossRef]

68. Calle, A.D.L.; Freije, I.; Ugarte, J.V.; Larrinaga, M.Á. Measuring the impact of digital capabilities on product-service innovation in Spanish industries. Int. J. Bus. Eviron. 2020, 11, 254-274. [CrossRef]

69. Bustinza, O.F.; Vendrell-Herrero, F.; Gomes, E. Unpacking the effect of strategic ambidexterity on performance: A cross-country comparison of MMNEs developing product-service innovation. Int. Bus. Rev. 2020, 29, 101569. [CrossRef]

70. Ariu, A. Crisis-proof services: Why trade in services did not suffer during the 2008-2009 collapse. J. Int. Econ. 2016, 98, 138-149. [CrossRef] 